[Regular Paper]

\title{
Separation of Aromatic Compounds Using Retrograde Crystallization in Supercritical Fluid
}

\author{
Takeshi SAKO ${ }^{\dagger 1) *}$, Masahito $\mathrm{SATO}^{\dagger 1)}$, Hidefumi TAKATO $^{\dagger 2)}$, and Masahiro KaTO ${ }^{\dagger 2)}$ \\ 1) Dept. of Chemical Systems, National Institute of Materials and Chemical Research, \\ Higashi 1-1, Tsukuba, Ibaraki 305 \\ 12) Dept. of Industrial Chemistry, Faculty of Engineering, Nihon University, \\ Tokusada, Tamura-cho, Koriyama, Fukushima 963-11
}

(Received April 21, 1995)

\begin{abstract}
We measured the solubilities of pure solids of anthracene, fluorene, acridine, and binary solid mixtures of phenanthrenetanthracene, fluorenetacridine in supercritical $\mathrm{CO}_{2}$ to determine the appropriate conditions for purification of polycyclic aromatics or heterocyclic compounds using a retrograde crystallization technique. Moreover we attempted to separate specific compounds from these two solid mixtures. As a result, it was found that (1) the crossover region of 2 kinds of solid mixtures in supercritical $\mathrm{CO}_{2}$ was sufficiently wide to isolate the solid component from the mixture; (2) the Peng-Robinson equation of state gave good predictions for solubilities of pure solids but gave poor predictions for those of the solid mixtures in supercritical $\mathrm{CO}_{2}$; and (3) phenanthrene, fluorene and acridine of high purity were separated from the solid mixtures, but anthracene was not as its amount predicted from the solubility data was very small.
\end{abstract}

\section{Introduction}

In the past decade, much attention has been paid to the use of supercritical fluids as extraction solvents in separation processes ${ }^{1)}$. The supercritical fluid extraction is especially useful for extracting relatively light hydrocarbons from viscous multicomponent mixtures such as distillation residuum oils and coal tars. However, one of the serious problems for its industrial application is that selectivity of separation is not high. Therefore, it is difficult to purify a specific component from a mixture with similar physical and chemical properties.

Recently several attempts have been made to purify valuable materials using retrograde crystallization from supercritical fluids ${ }^{2) 4}$. The technique is based on the following: solubility isotherms at different temperatures intersect at certain pressure called crossover pressure; an increase in temperature causes a decrease in solubility below this pressure, while the opposite effect occurs above the pressure; and a specific component is deposited selectively from the supercritical fluid saturated with many kinds of solutes when each solute has a different crossover

* To whom correspondence should be addressed. pressure.

The advantage of this purification technique is that it has high separation selectivity. It can avoid thermal decomposition and polymerization of the solutes because it is operated near room temperature, and it does not use toxic solvents. On the other hand, there are such problems as requiring experimental data on phase equilibrium to determine the operating conditions and that the solvent power of the supercritical fluid is not so large for low volatile hydrocarbons.

The objectives of the present work are to determine the crossover pressures of polycyclic aromatics or heterocyclic compounds in supercritical fluids based on the solubility data and to purify the compounds using the retrograde crystallization technique. These compounds are promising as new materials for advanced polymers and fine chemicals. Phenanthrenetanthracene and fluorene+acridine were chosen as solid mixtures to be purified and supercritical $\mathrm{CO}_{2}\left(\mathrm{SC}-\mathrm{CO}_{2}\right)$ was used as supercritical fluid.

\section{Experimental Section}

Solubilities of pure solids and solid mixtures in $\mathrm{SC}-\mathrm{CO}_{2}$ were measured with a flow-type apparatus. Details of the apparatus and procedures are available elsewhere ${ }^{5)}$. 


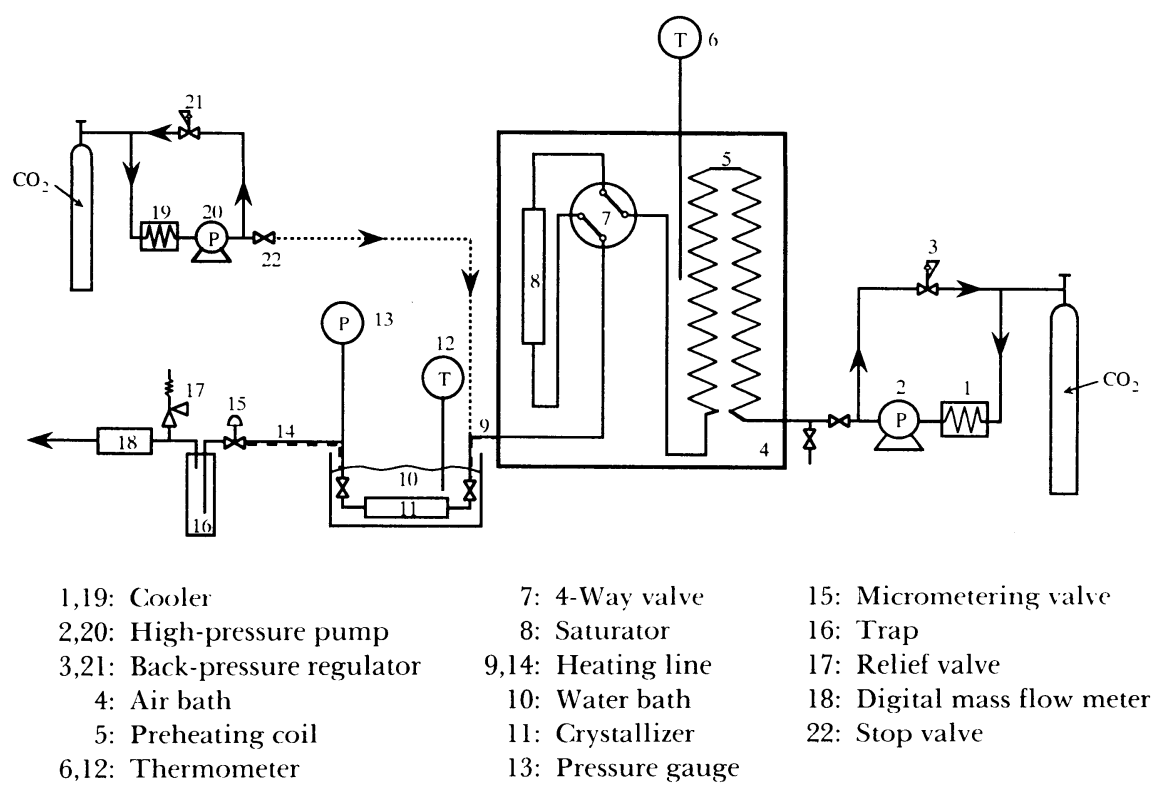

Fig. 1 Experimental Apparatus Used for Retrograde Crystallization

A schematic flow diagram of the apparatus used for retrograde crystallization is shown in Fig. 1. Liquid $\mathrm{CO}_{2}$ compressed by a high pressure pump(2) flowed into a preheating coil(5) and became supercritical. The pressure of $\mathrm{SC}-\mathrm{CO}_{2}$ was controlled by a back-pressure regulator(3). $\mathrm{SC}-\mathrm{CO}_{2}$ then entered a saturator(8) placed in the first constant temperature bath(4), and the phase equilibrium between $\mathrm{SC}-\mathrm{CO}_{2}$ and solid mixture was achieved in this vessel. The saturator was a $25-\mathrm{cm}$ long stainless tube, $6-\mathrm{mm}$ inner diameter, and packed with a granulated solid mixture. After flowing past the saturator, $\mathrm{SC}-\mathrm{CO}_{2}$ dissolving the solid mixture entered a crystallizer(11), $8 \mathrm{~mm}$ in O.D. $\times 6 \mathrm{~mm}$ in I.D. $\times 200 \mathrm{~mm}$ in length, immersed in the second constant temperature bath(10) and the specific component was deposited out of $\mathrm{SC}-\mathrm{CO}_{2}$ due to the decrease in its solubility by temperature change. After passing through the crystallizer, the flow was expanded to atmospheric pressure by a micrometering valve(15). The valve was also used to adjust the flow rate which was measured by a digital mass flowmeter(18). The line between the air bath and the water bath was heated at the same temperature as that of the air bath to avoid solid deposition. $\mathrm{SC}-\mathrm{CO}_{2}$ was forced to flow for more than 12 hours with a flow rate of $10-20 \mathrm{~cm}^{3} / \mathrm{min}$ at $273 \mathrm{~K}$ and $101.3 \mathrm{kPa}$.

At the end of the run, $\mathrm{SC}-\mathrm{CO}_{2}$ in the crystallizer was purged by pure $\mathrm{CO}_{2}$, whose pressure was almost the same as that in the crystallizer, supplied through a valve(22), to minimize contamination by deposition of solids in $\mathrm{SC}-\mathrm{CO}_{2}$ during depressurization. The composition of the precipitate in the crystallizer was analyzed by using a gas chromatograph.

In both apparatuses for solubility measurement and purification, the temperature was measured with a calibrated platinum resistance thermometer with an accuracy of $\pm 0.1 \mathrm{~K}$, and the pressure was measured by using a calibrated digital pressure gauge with an accuracy of $\pm 0.01 \mathrm{MPa}$. The GC column was a $0.25 \mathrm{~mm}$ (dia.) $\times 30 \mathrm{~m}$ DB-1 column and a FID detector was used. Analytical accuracy of the solutes was within $1.0 \%$.

The purity of $\mathrm{CO}_{2}$ gas was more than $99.9 \mathrm{vol} \%$; that of phenanthrene, anthracene and acridine more than $98 \mathrm{wt} \%$; and that of fluorene more than $95 \mathrm{wt} \%$. These were used without further purification.

\section{Solubilities of Pure Solids and Solid Mixtures in $\mathrm{SC}-\mathrm{CO}_{2}$}

Solubilities of pure solids of anthracene, fluorene, acridine, and binary solid mixtures of phenanthrenetanthracene, fluorene+acridine in $\mathrm{SC}-\mathrm{CO}_{2}$ were measured in the temperature range from 308 to $338 \mathrm{~K}$ to determine the operating conditions for the retrograde crystallization process. The solubility data of three pure solids are presented in Tables 1 through 3. The solubility data of anthracene were compared with those in the literature6),7) to check the reliability of the experimental apparatus and procedure. The 
Table 1 Solubility of Anthracene in Supercritical $\mathrm{CO}_{2}$

\begin{tabular}{ccc}
\hline $\begin{array}{c}\text { Temperature } \\
{[\mathrm{K}]}\end{array}$ & $\begin{array}{c}\text { Pressure } \\
\text { [MPa] }\end{array}$ & $\begin{array}{c}\text { Solubility } \\
\text { [mole fraction] }\end{array}$ \\
\hline 308.1 & 9.90 & $3.470 \mathrm{e}-05$ \\
308.2 & 12.26 & $4.670 \mathrm{e}-05$ \\
308.1 & 14.02 & $5.490 \mathrm{e}-05$ \\
308.2 & 16.87 & $6.440 \mathrm{e}-05$ \\
308.1 & 19.81 & $7.080 \mathrm{e}-05$ \\
308.1 & 22.95 & $7.590 \mathrm{e}-05$ \\
308.1 & 25.60 & $8.260 \mathrm{e}-05$ \\
308.2 & 28.24 & $8.640 \mathrm{e}-05$ \\
\hline 337.9 & 10.20 & $4.000 \mathrm{e}-06$ \\
337.8 & 11.67 & $1.250 \mathrm{e}-05$ \\
338.1 & 14.32 & $5.000 \mathrm{e}-05$ \\
338.1 & 16.08 & $7.990 \mathrm{e}-05$ \\
337.9 & 18.24 & $1.108 \mathrm{e}-04$ \\
337.9 & 19.81 & $1.363 \mathrm{e}-04$ \\
338.1 & 21.77 & $1.653 \mathrm{e}-04$ \\
\hline
\end{tabular}

Table 2 Solubility of Fluorene in Supercritical $\mathrm{CO}_{2}$

\begin{tabular}{ccc}
\hline $\begin{array}{c}\text { Temperature } \\
{[\mathrm{K}]}\end{array}$ & $\begin{array}{c}\text { Pressure } \\
{[\mathrm{MPa}]}\end{array}$ & $\begin{array}{c}\text { Solubility } \\
\text { [mole fraction] }\end{array}$ \\
\hline 318.1 & 12.94 & $1.646 \mathrm{e}-03$ \\
318.1 & 14.61 & $2.031 \mathrm{e}-03$ \\
318.1 & 16.77 & $2.481 \mathrm{e}-03$ \\
318.1 & 18.53 & $2.642 \mathrm{e}-03$ \\
318.1 & 20.59 & $2.885 \mathrm{e}-03$ \\
318.1 & 22.95 & $3.078 \mathrm{e}-03$ \\
\hline 338.1 & 13.73 & $1.219 \mathrm{e}-03$ \\
338.1 & 14.71 & $1.720 \mathrm{e}-03$ \\
338.1 & 15.40 & $2.071 \mathrm{e}-03$ \\
338.1 & 16.48 & $2.644 \mathrm{e}-03$ \\
338.1 & 17.46 & $3.017 \mathrm{e}-03$ \\
338.1 & 19.81 & $3.859 \mathrm{e}-03$ \\
338.1 & 21.38 & $4.423 \mathrm{e}-03$ \\
338.2 & 24.03 & $5.257 \mathrm{e}-03$ \\
\hline
\end{tabular}

Table 3 Solubility of Acridine in Supercritical $\mathrm{CO}_{2}$

\begin{tabular}{ccc}
\hline $\begin{array}{c}\text { Temperature } \\
{[\mathrm{K}]}\end{array}$ & $\begin{array}{c}\text { Pressure } \\
{[\mathrm{MPa}]}\end{array}$ & $\begin{array}{c}\text { Solubility } \\
\text { [mole fraction] }\end{array}$ \\
\hline 318.2 & 12.94 & $7.154 \mathrm{e}-04$ \\
318.2 & 14.71 & $9.105 \mathrm{e}-04$ \\
318.2 & 16.77 & $1.069 \mathrm{e}-03$ \\
318.2 & 18.63 & $1.196 \mathrm{e}-03$ \\
318.0 & 20.69 & $1.309 \mathrm{e}-03$ \\
318.1 & 22.75 & $1.408 \mathrm{e}-03$ \\
\hline 338.1 & 13.93 & $4.295 \mathrm{e}-04$ \\
338.2 & 15.30 & $6.528 \mathrm{e}-04$ \\
338.1 & 16.77 & $9.764 \mathrm{e}-03$ \\
338.1 & 17.75 & $1.123 \mathrm{e}-03$ \\
338.1 & 19.32 & $1.405 \mathrm{e}-03$ \\
338.0 & 20.59 & $1.659 \mathrm{e}-03$ \\
338.1 & 21.77 & $1.764 \mathrm{e}-03$ \\
338.1 & 23.63 & $2.003 \mathrm{e}-03$ \\
\hline
\end{tabular}

results are shown in Fig. 2. Our data agreed well with those of literature reported by Johnston $e t$ al. The solubility isotherms of solid mixtures of phenanthrene+anthracene and fluorene+acridine are shown graphically in Figs. 3 and 4 . The crossover pressure, in which the isotherms at different temperatures intersect each other, was 16.1 $\mathrm{MPa}$ for phenanthrene and $14.6 \mathrm{MPa}$ for anthracene at 308 and $338 \mathrm{~K}$, and $17.2 \mathrm{MPa}$ for fluorene and 19.0 MPa for acridine at 318 and

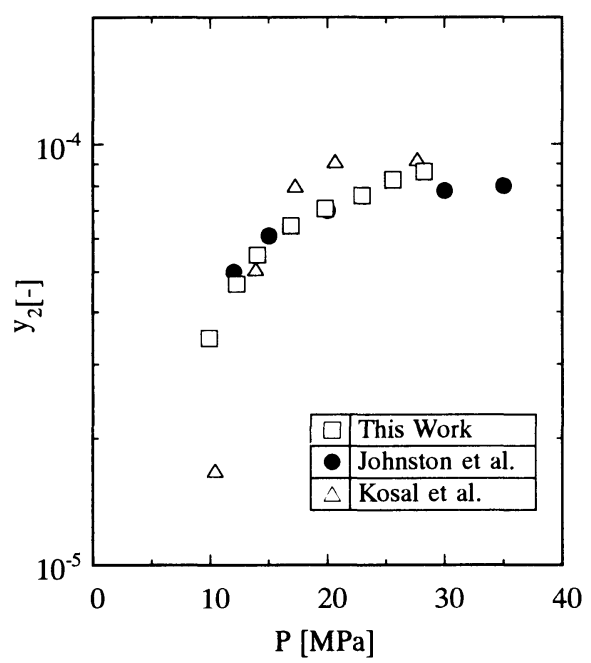

Fig. 2 Comparison of Experimental Solubilities of Anthracene in $\mathrm{SC}-\mathrm{CO}_{2}$ at $308 \mathrm{~K}$ with Those in Literature

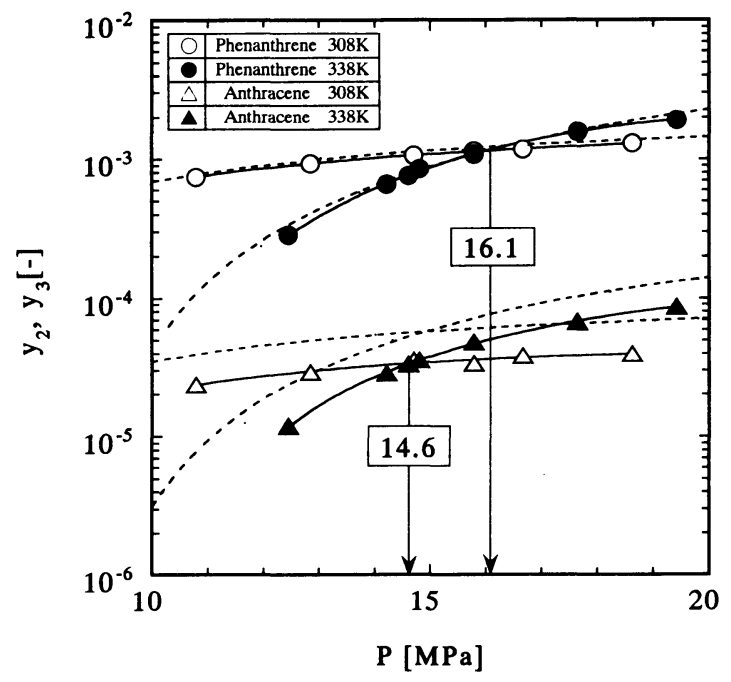

-..: Solubilities of corresponding pure solids.

Fig. 3 Solubility Isotherms of Mixture of Phenanthrene+Anthracene in $\mathrm{SC}_{1}-\mathrm{CO}_{2}$ at 308 and $338 \mathrm{~K}$

$338 \mathrm{~K}$. The temperature dependence of solubility reversed at the crossover pressure. The increase in temperature led to the increase in solubility above the crossover pressure, while the same condition of temperature led to the decrease below the crossover pressure. Figure 3 also shows a comparison of the solubilities of pure solids with those of solid mixture of phenanthrenetanthracene at 308 and $338 \mathrm{~K}$. The solubility of more soluble component (phenanthrene) in the solid mixture was almost the same as that of the corresponding pure solid, 


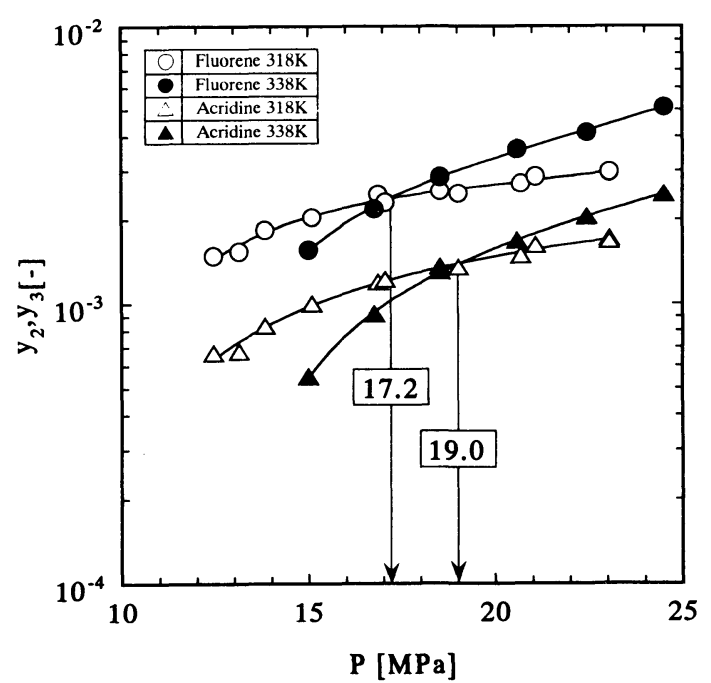

Fig. 4 Solubility Isotherms of Mixture of Fluorene+Acridine in $\mathrm{SC}-\mathrm{CO}_{2}$ at 318 and $338 \mathrm{~K}$

while the solubility of less soluble component (anthracene) in the mixture was smaller than that of the pure solid. The solubility change for the more soluble component was common but, for the less soluble one, it was not common as in usual cases. by

Solid solubility $y_{i}$ in a supercritical fluid is given

$$
y_{i}=\frac{p_{i}^{\text {sat }}}{p} \frac{1}{\phi_{i}^{\mathrm{v}}} \exp \left[\frac{v_{i}^{\mathrm{S}}\left(p-p_{i}^{\mathrm{sat}}\right)}{R T}\right]
$$

where $p_{i}^{\text {sat }}$ is the vapor pressure of a solid, $v_{i}^{\mathrm{S}}$ is the molar volume of the solid, and $\phi_{i}^{\mathrm{v}}$ is the fugacity coefficient of the solid in the supercritical fluid. The $\phi_{i}^{\mathrm{v}}$ was calculated from the Peng-Robinson (PR) equation of state8):

$$
p=\frac{R T}{v-b}-\frac{a}{v(v+b)+b(v-b)}
$$

The parameters of a mixture, $a$ and $b$, were determined by

$$
\begin{aligned}
& a=\sum_{i} \sum_{j} y_{i} y_{j}\left(1-k_{i j}\right)\left(a_{i} a_{j}\right)^{0.5} \\
& b=\sum_{i} \sum_{j} y_{i} y_{j}\left(1-l_{i j}\right)\left[\frac{b_{i}+b_{j}}{2}\right]
\end{aligned}
$$

where the parameters of a pure component, $a_{i}$ and $b_{i}$, were calculated from the critical properties and acentric factor of the component, and the binary interaction parameters, $k_{i j}$ and $l_{i j}$, were determined from the best fit to the solubility data of the pure solid in the supercritical fluid. $p_{i}^{\text {sat }}$ was calculated from the Antoine equation:

$$
\log p_{i}^{\text {sat }}=A-\frac{B}{T+C}
$$

Most of the required properties and Antoine

\begin{tabular}{|c|c|c|c|c|c|c|c|}
\hline \multirow{2}{*}{ Component } & \multirow{2}{*}{$\begin{array}{c}T_{\mathrm{C}} \\
{[\mathrm{K}]}\end{array}$} & \multirow{2}{*}{$\begin{array}{c}p_{\mathrm{C}} \\
{[\mathrm{MPa}]}\end{array}$} & \multirow{2}{*}{$\begin{array}{c}\omega \\
{[-]}\end{array}$} & \multirow{2}{*}{$\begin{array}{c}v^{\mathrm{s}}(298 \mathrm{~K}) \\
{\left[\mathrm{cm}^{3} / \mathrm{mol}\right]}\end{array}$} & \multicolumn{3}{|c|}{$\log p^{\text {sat }}[\mathrm{bar}]=A-B /(T[K]+C)$} \\
\hline & & & & & $A$ & $B$ & $C$ \\
\hline $\mathrm{CO}_{2}$ & 304.2 & 7.37 & 0.225 & - & - & - & - \\
\hline Phenanthrene & 873 & $2.89^{a)}$ & 0.431 & 167.6 & 9.6310 & 4873.4 & 0 \\
\hline Anthracene & 869.3 & $2.89^{\text {a) }}$ & 0.426 & 142.6 & 7.1464 & 4397.6 & 0 \\
\hline Fluorene & $820.8^{\text {a) }}$ & $2.99^{\text {a) }}$ & 0.428 & 138.2 & 9.2046 & 4561.8 & 0 \\
\hline Acridine & $883.2^{\text {a) }}$ & $3.19^{\mathrm{a})}$ & 0.498 & 178.3 & 8.7208 & 4740.1 & 0 \\
\hline
\end{tabular}
constants of the pure solids are available in the literature9) 11) and some critical properties have been estimated by Lydersen method ${ }^{12)}$. The

Table 4 Physicochemical Properties of Pure Components

a) $T_{\mathrm{C}}, p_{\mathrm{C}}$ were estimated by Lydersen method ${ }^{12}$.

Table 5 Binary Interaction Parameters and Correlated Results with Peng-Robinson Equation of State

\begin{tabular}{lllcc}
\hline \multicolumn{1}{c}{ System } & $T[\mathrm{~K}]$ & $k_{i j}$ & $l_{i j}$ & Error [\%] $^{\text {a) }}$ \\
\hline $\mathrm{CO}_{2}+$ Phenanthrene $^{5)}$ & 308.3 & 0.1104 & -0.00415 & 8.5 \\
$\mathrm{CO}_{2}+$ Anthracene & 337.9 & 0.1093 & -0.01162 & 3.3 \\
& 308.1 & 0.1659 & 0.0803 & 4.7 \\
$\mathrm{CO}_{2}+$ Fluorene & 338.0 & 0.1122 & 0.00248 & 7.1 \\
$\mathrm{CO}_{2}+$ Acridine & 318.1 & 0.0639 & -0.0646 & 1.6 \\
& 338.1 & 0.0425 & -0.1034 & 2.7 \\
& 318.2 & 0.00323 & -0.2457 & 2.4 \\
\hline
\end{tabular}

a) $\operatorname{Error}(\%)=\frac{1}{n} \sum_{i=1}^{n} \frac{\left|y_{i}^{\exp }-y_{i}^{\text {cal }}\right|}{y_{i}^{\exp }} \times 100$. 


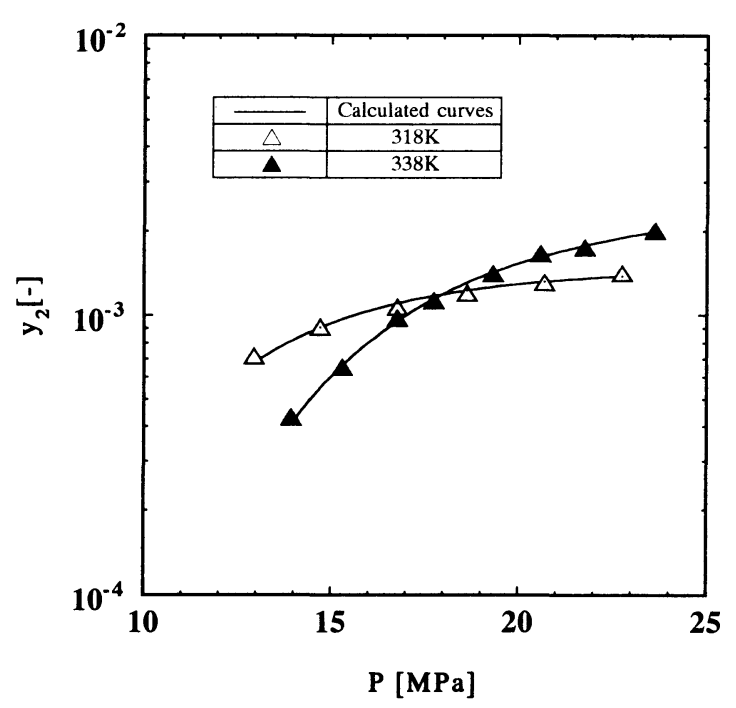

Fig. 5 Calculated Solubilities of Acridine in $\mathrm{SC}-\mathrm{CO}_{2}$ with PR Equation

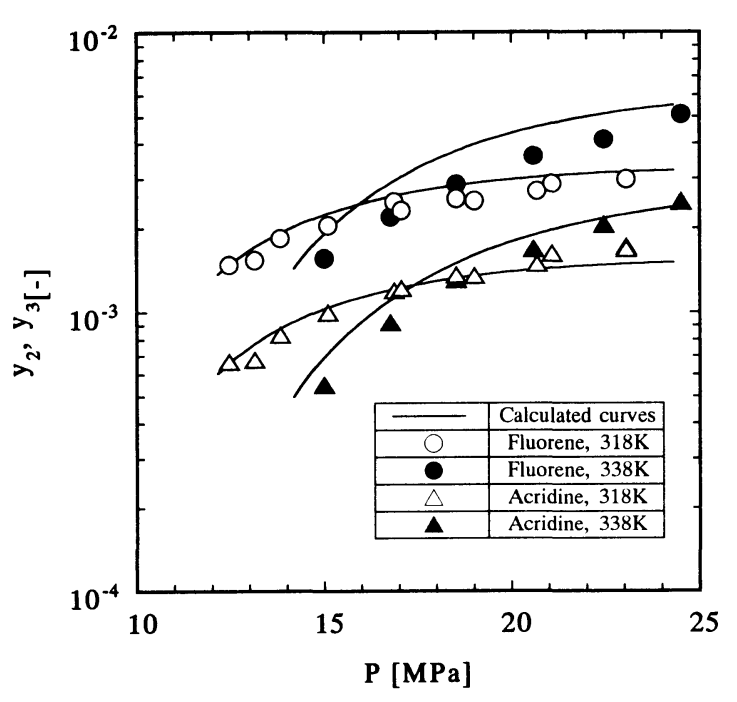

Fig. 6 Calculated Solubilities of Mixture of Fluorene+ Acridine in $\mathrm{SC}-\mathrm{CO}_{2}$ with PR Equation $\left(k_{23}=\right.$ $l_{23}=0$ )

values are summarized in Table 4.

The regressed binary interaction parameters and correlated deviations for $\mathrm{CO}_{2}+$ pure solid systems are given in Table 5. Calculated results of the $\mathrm{CO}_{2}$ +acridine system are given in Fig. 5. The PR equation correlated the solubilities of the pure solids satisfactorily. Figure 6 shows the solubility of the solid mixture of fluorene+acridine predicted by the PR equation, where the binary interaction parameters between the two solids were assumed to be zero to the first approximation. The predicted results were in fairly good agreement with the experimental results at $318 \mathrm{~K}$ but not

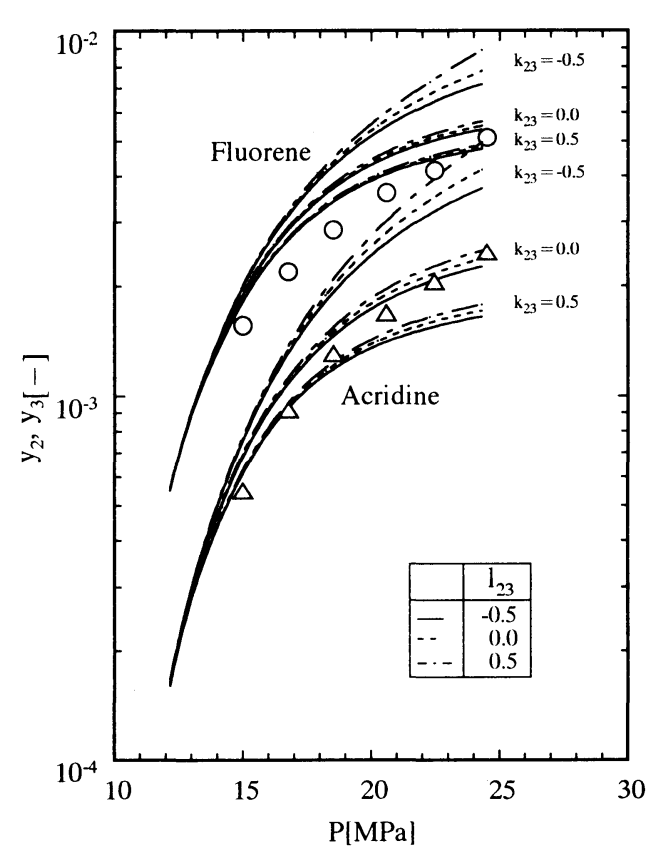

$k_{12}=0.0425, l_{12}=-0.1034, k_{13}=0.00080, l_{13}=-0.2486$.

Fig. 7 Influence of $k_{23}$ and $l_{23}$ on Calculated Solubilities for $\mathrm{CO}_{2}(1)+$ Fluorene(2)+Acridine(3) System at $338 \mathrm{~K}$

at $338 \mathrm{~K}$. Figure 7 shows the influence of $k_{23}$ and $l_{23}$ on the calculated result of the solid solubility for the $\mathrm{CO}_{2}+$ fluorene + acridine system at $338 \mathrm{~K}$, where subscripts 2 and 3 mean the 2 kinds of solids in $\mathrm{SC}-\mathrm{CO}_{2}$. Increase in $k_{23}$ at constant $l_{23}$ caused a decrease in the solubility of both solids, and increase in $l_{23}$ at constant $k_{23}$ gave the opposite effect on the solid solubility. Judging from Fig. 7, the PR equation could not satisfactorily predict the solubility of solid mixtures especially in the region where solubility changed with pressure steeply. As a result, the crossover pressure of the solid mixtures had to be determined experimentally.

\section{Purification of Binary Solid Mixtures}

As shown in Figs. 3 and 4, the crossover region between the crossover pressures of both solid components was from 14.6 to $16.1 \mathrm{MPa}$ for $\mathrm{CO}_{2}+$ phenanthrenetanthracene system and from 17.2 to $19.0 \mathrm{MPa}$ for $\mathrm{CO}_{2}+$ fluorene+acridine system. Purification of phenanthrene and anthracene in the mixture was performed at 15.0 and $15.7 \mathrm{MPa}$ in the crossover region. Under these pressure conditions, lowering the temperature from 338 to $308 \mathrm{~K}$ should cause deposition of pure anthracene from $\mathrm{SC}-\mathrm{CO}_{2}$ containing both phenanthrene and 
Phenanthrene

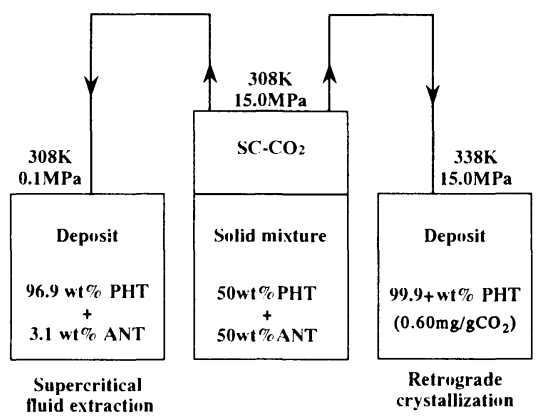

Anthracene

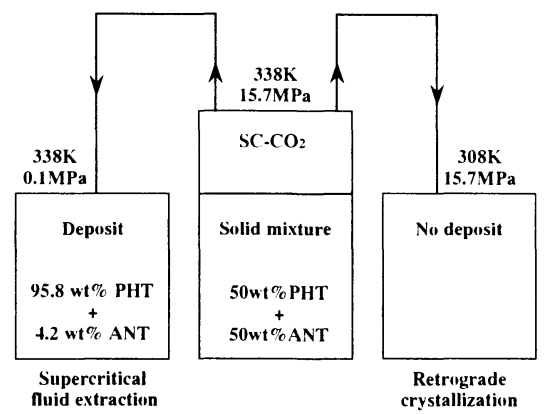

PHT: Phenanthrene, ANT: Anthracene.

Fig. 8 Comparison of Recovery of Phenanthrene and Anthracene from Their Mixture Using Retrograde Crystallization with That Using Conventional Supercritical Fluid Extraction

Fluorene

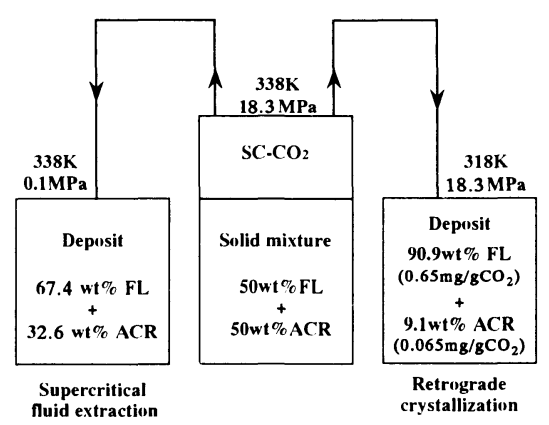

Acridine

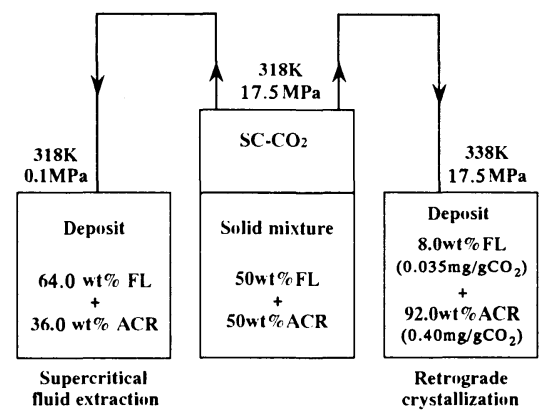

FL: Fluorene, ACR: Acridine.

Fig. 9 Comparison of Recovery of Fluorene and Acridine from Their Mixture Using Retrograde Crystallization with That Using Conventional Supercritical Fluid Extraction

anthracene, while raising the temperature should cause deposition of pure phenanthrene owing to the retrograde crystallization phenomenon, which is the reverse solubility behavior of solubility versus temperature. On the other hand, purification of the solid mixture of fluorene+acridine was carried out by increasing the temperature from 318 to $338 \mathrm{~K}$ at $17.5 \mathrm{MPa}$ to precipitate pure acridine and by decreasing it from 338 to $318 \mathrm{~K}$ to precipitate pure fluorene at $18.3 \mathrm{MPa}$. Theoretically, this method has infinite selectivity in a single stage for purification of a solid mixture containing two components.

Figures 8 and 9 present the experimental results for purification of the solid mixtures of phenanthrene+anthracene and fluorene+acridine using this process. Phenanthrene was deposited and its purity was more than $99.9 \mathrm{wt} \%$ but none was deposited for anthracene from the $50 \mathrm{wt} \%-50 \mathrm{wt} \%$ mixture. This was because the deposit of anthracene was very small, less than $0.04 \mathrm{mg} /$ $\mathrm{gCO}_{2}$, and it was difficult to entrap it in the crystallizer. The maximum purity of fluorene was $90.9 \mathrm{wt} \%$ and that of acridine $92.0 \mathrm{wt} \%$. The contamination of the deposits was caused by the insufficient replacement of $\mathrm{SC}-\mathrm{CO}_{2}$ dissolving both solutes by pure $\mathrm{CO}_{2}$. The impurities precipitated during depressurization at the end of the experiment. On the other hand, a single-stage conventional supercritical fluid extraction gave much less selectivity for separation of solid mixtures. Compositions of the extracts predicted from the solubility data are also given in these figures.

Amounts of the precipitates per gram of $\mathrm{CO}_{2}$ are given in the parentheses in Figs. 8 and 9. The 
recovery, which was defined by the ratio of the actual amount of the precipitate to the expected amount of the precipitate from solubility data, was $50-75 \%$ for each experiment except for anthracene.

\section{Conclusions}

Solubilities of pure solids of anthracene, fluorene, acridine, and solid mixtures of phenanthrene+anthracene, fluorene+acridine in supercritical $\mathrm{CO}_{2}$ were measured in the temperature range from 308 to $338 \mathrm{~K}$. Their solubility data showed that the crossover region for both mixtures was sufficiently wide to isolate each component from the mixtures by using the retrograde crystallization technique. Experimental data were correlated by the Peng-Robinson equation of state with 2-parameter mixing rules. This equation correlated the solubility of the pure solids well. However it gave poor prediction for the solid mixtures in supercritical $\mathrm{CO}_{2}$.

Separation of each component in the mixtures of phenanthrene+anthracene and fluorene+acridine was examined by using retrograde crystallization from supercritical $\mathrm{CO}_{2}$. As a result, the solids of high purity could be obtained from the mixtures except for anthracene.

\section{Acknowledgment}

The authors wish to thank Miss S. Nagasaki for her assistance in the experimental work.

\section{Nomenclatures}

$\begin{array}{llr}\begin{array}{l}A, B, C \\ a\end{array} & \text { Antoine constants } \\ & \text { : energy parameter of equation of state } & {[-]} \\ b & \text { : size parameter of equation of state } & {\left[\mathrm{MPa} \mathrm{cm}^{6} \mathrm{~mol}^{-2}\right]} \\ k, l & \text { : binary interaction parameters } & {\left[\mathrm{cm}^{3} \mathrm{~mol}^{-1}\right]} \\ & & {[-]}\end{array}$

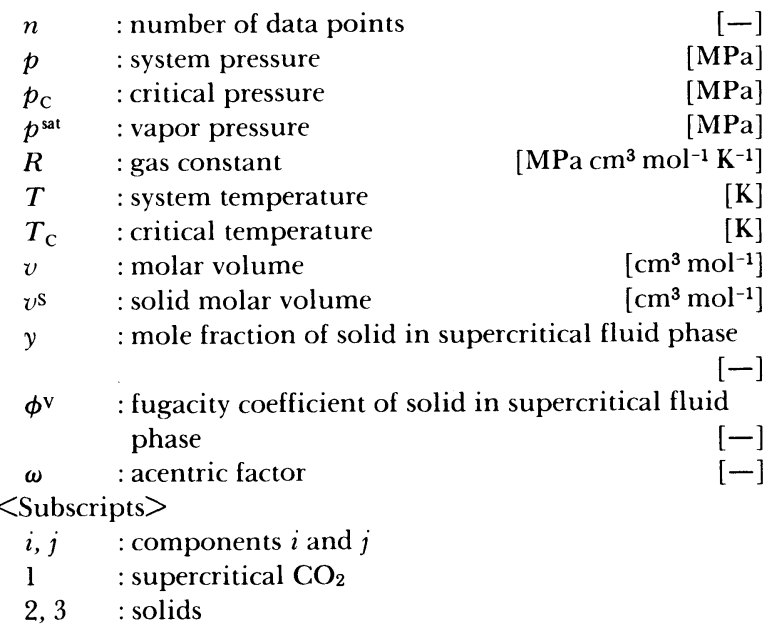

\section{References}

1) Kiran, E., Sengers, J. M. H. L. (Eds.), "Supercritical Fluid, Fundamentals and Application," NATO ASI Series, vol. 273, Kluwer Academic Publishers, London (1993).

2) Chimowitz, E. H., Pennisi, K. J., AIChE J., 32, 1665 (1986).

3) Johnston, K. P., Barry, S. E., Read, N. K., Holcomb, T. R., Ind. Eng. Chem. Res., 26, 2372 (1987).

4) Sako, T., Sato, M., Yamane, S., J. Chem. Eng. Jpn., 23, 770 (1990).

5) Sako, T., Yamane, S., Negishi, A., Sato, M., Sekiyu Gakkaishi, 37, (3), 321 (1994).

6) Dobbs, J. M., Johnston, K. P., Ind. Eng. Chem. Res., 26, 1476 (1987).

7) Kosal, E., Holder, G. D., J. Chem. Eng. Data, 32, 148 (1987).

8) Peng, D. Y., Robinson, D. B., Ind. Eng. Chem. Fundam., 15, 59 (1976)

9) Reid, R. C., Prausnitz, J. M., Sherwood, T. K., "The Properties of 'Gases and Liquids," McGraw-Hill, New York (1977), p. 629.

10) Ziger, D. H., Eckert, C. A., Ind. Eng. Chem., Process Des. Dev., 22, 582 (1983).

11) Schmitt, W. J., Reid, R. C., "Supercritical Fluid Technology," Elsevier, New York (1985), p. 123.

12) Lydersen, A. L., Univ. Wisconsin Coll. Eng., Eng. Exp. Stn. Rep. 3, Madison, Wis. April (1955). 
要旨

\section{超臨界流体中での逆行析出現象を用いる芳香族化合物の分離}

佐古 猛 $^{+1)}$, 佐藤 畺士 ${ }^{\dagger 1)}$, 高遠 秀文 ${ }^{\dagger 2)}$, 加藤 昌弘 ${ }^{\dagger 2)}$

†1) 物質工学工業技術研究所 化学システム部, 305 茨城県つくば市東 1-1

†2) 日本大学工学部工業化学科, 963-11 福島県郡山市田村町徳定

逆行析出分離法による多環芳香族および複素環式化合物の精 製に必要な基礎デー夕を得るために, 超臨界 $\mathrm{CO}_{2}$ 中の純アン トラセン, 純フルオレン, 純アクリジン, フェナントレン+ア ントラセン混合物, フルオレン+アクリジン混合物の溶解度を 測定した。さらに，上記の 2 種類の混合物から各成分を単離 することを試みた。その結果，（1）超臨界 $\mathrm{CO}_{2}$ 中において 2 種類の混合物の交差圧力領域は十分広いので, 混合物中の各成
分を単離できること，(2) Peng-Robinson 状態方程式は超臨界 $\mathrm{CO}_{2}$ 中の純固体の溶解度を良好に表すことができるが, 固体 混合物の場合には推算誤差が大きくなること，(3)フェナント レン, フルオレンおよびアクリジンは混合物中から高純度で単 離できるが, アントラセンは溶解度データから予想されるよう に析出量が非常に少ないために，分析可能な量を捕集すること が困難であることが明らかになった。

\section{Keywords}

Separation, Retrograde crystallization, Solubility, Supercritical carbon dioxide, Aromatics 